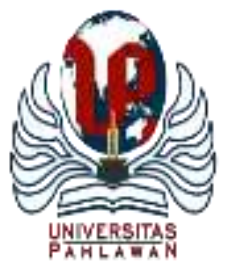

Edukatif : Jurnal Ilmu Pendidikan Volume 3 Nomor 6 Tahun 2021 Halm 4556 - 4567

EDUKATIF: JURNAL ILMU PENDIDIKAN

Research \& Learning in Education

https://edukatif.org/index.php/edukatif/index

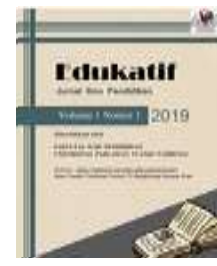

\title{
Analisis Tata Kelola Perguruan Tinggi Vokasi dan Indeks Kepuasan Siswa pada Politeknik Perkeretaapian Indonesia Madiun
}

\author{
Damar Isti Pratiwi ${ }^{1 凶}$, Septiana Widi Astuti ${ }^{2}$, Armyta Puspitasari $^{3}$, Ainun Fikria ${ }^{4}$ \\ Politeknik Perkeretaapian Indonesia Madiun, Indonesia ${ }^{1,2,3,4}$ \\ E-mail : $\underline{\text { damar@ppi.ac.id }}{ }^{1}, \underline{\text { septiana@ppi.ac.id }}^{2}, \underline{\text { armyta@ppi.ac.id }}^{3}, \underline{\text { ainun @ppi.ac.id }}^{4}$
}

\begin{abstract}
Abstrak
Pengembangan sumber daya manusia yang utuh dapat dilakukan secara dinamis dan berkelanjutan melalui perguruan tinggi vokasi yang menekankan kompetensi dan keahlian praktikal yang dapat diterima di dunia kerja. Untuk itu diperlukan tata kelola perguruan tinggi vokasi yang efektif dan efisien sehingga dapat menghasilkan lulusan yang profesional, berkualitas dan memiliki daya saing di tingkat lokal dan global. Metode yang digunakan dalam penelitian ini adalah studi kasus dengan analisis kualitatif dan kuantitatif. Hasil analisis kualitatif menunjukkan bahwa serangkaian standar yang telah ditetapkan pemerintah melalui Badan Akreditasi Nasional Perguruan Tinggi perlu dipenuhi dengan menerapkan langkah-langkah manajemen strategi untuk meningkatkan kualitas pendidikan. Perubahan yang dinamis dan fleksibel harus terus menerus dilakukan untuk menjawab tantangan perubahan dunia dengan adanya kemajuan teknologi, revolusi industri 4.0. dan learning 5.0. Pada analisis kuantitatif, indeks kepuasaan siswa menunjukkan kecenderungan positif terhadap tata kelola Perguruan Tinggi yang meningkat. Implikasi dari peningkatan layanan pendidikan dan kompetensi lulusan diharapkan dapat memenuhi kebutuhan stakeholders dan mendukung perekonomian Indonesia.
\end{abstract}

Kata Kunci: pendidikan berkualitas; PPI Madiun; perguruan tinggi vokasi; SDM Perhubungan Darat; tata kelola organisasi.

\begin{abstract}
Human resource development could be done completely in dynamic and holistic way through vocational universities which focus on the acceleration of competence and practical skills in work places. Hence, it is needed effective and efficient organizational university management to result professional, qualified and competitive outputs in local and global area. This used case study research design with quantitative and qualitative analysis. The results of qualitative analysis showed that a set of standards which have been determined by BAN-PT need to be fulfilled by implementing strategic management concepts to improve education quality. The dynamic and flexible changes have to be done continuously to answer world change challenge with technological development, 4.0 industry revolution and 5.0 learning innovation. On the quantitative analysis, students' satisfaction index showed positive trends towards the development of university organization. In conclusion, the implication of educational improvement quality and competence outputs could fulfill stakeholders needs and support Indonesian economy.
\end{abstract}

Keywords: qualified education; PPI Madiun; vocational university; land transportation human resources; organizational management.

Copyright (c) 2021 Damar Isti Pratiwi, Septiana Widi Astuti, Armyta Puspitasari, Ainun Fikria $\triangle$ Corresponding author

Email : damar@ppi.ac.id

DOI : https://doi.org/10.31004/edukatif.v3i6.1491 
4557 Analisis Tata Kelola Perguruan Tinggi Vokasi dan Indeks Kepuasan Siswa pada Politeknik Perkeretaapian Indonesia Madiun - Damar Isti Pratiwi, Septiana Widi Astuti, Armyta Puspitasari, Ainun Fikria

DOI : https://doi.org/10.31004/edukatif.v3i6.1491

\section{PENDAHULUAN}

Pendidikan memiliki peranan penting dalam pengembangan manusia seutuhnya dan pembangunan masyarakat Indonesia seluruhnya seperti yang tertuang pada cita-cita luhur bangsa Indonesia dalam pembukaan UUD 1945. Pengembangan manusia harus dilakukan secara utuh, yang mencakup daya pikir, daya nalar, daya fisik, dan penguasaan ilmu pengetahuan dan teknologi serta olahraga dan seni (Slamet, 2011). Sehingga diharapkan akan menghasilkan manusia yang sanggup dan mampu berperan aktif dalam membangun masyarakat Indonesia seluruhnya. Dalam hal ini, pendidikan memegang peranan yang vital dalam pengembangan sumber daya manusia, terutama di era globalisasi dimana perkembangan ilmu pengetahuan dan teknologi tumbuh dengan cepat dan menyebar secara global.

Tatanan dunia baru sekarang ini telah berubah ke arah perdagangan bebas yang ditandai dengan semakin terbukanya peluang kerja sama antar negara. Hal tersebut menimbulkan persaingan dalam hal barang, jasa, modal dan tenaga kerja (sumber daya manusia) (Model Pendidikan Vokasi yang Efektif dan Efisien, 2008). Untuk dapat berkiprah dalam persaingan dunia global, maka diperlukan sumber daya manusia yang kompeten, adaptif dan antisipatif dalam menyikapi berbagai perubahan sekarang ini. Para pelajar sebagai generasi penerus bangsa dituntut untuk terbuka dalam menyikapi perubahan, mampu bagaimana belajar, memiliki ketrampilan yang memadai, mudah dilatih ulang, serta mempunyai karakter yang kuat untuk berkembang di masa yang akan datang (Amin, 2017).

Pendidikan vokasi dapat menjadi salah satu jawaban terhadap adanya perubahan global tersebut, yang mana pada pendidikan vokasi lebih ditekankan keahlian praktikal yang dibutuhkan untuk langsung terjun ke dunia kerja (Indrawan et al., 2020). Wagner (2008) menuliskan tujuh ketrampilan yang berguna dalam menghadapi globalisasi, yaitu (1) Critical thinking and problem solving; (2) Collaboration across networks and leading by influence; (3) Agility and adaptability; (4) Initiative and entrepreneurship; (5) Effective oral and written communication; (5) Accessing and analyzing information; dan (6) Curiosity and imagination.

Untuk itulah pemerintah Indonesia telah membentuk Direktorat Jenderal Pendidikan Vokasi untuk menyikapi tantangan global ini melalui Peraturan Presiden No 82 tahun 2019 tentang adanya Ditjen Pendidikan Vokasi pada Kementerian Pendidikan dan Kebudayaan (Presiden Republik Indonesia, 2019). Arah kebijakan pendidikan vokasi yang tertuang pada Rencana Strategis Pendidikan Vokasi 2020-2024 Ditjen Pendidikan Vokasi (Ditjen Pendidikan Vokasi, 2020) menyebutkan bahwa melalui pembangunan sumber daya manusia yang adaptif dan berkelanjutan, bangsa Indonesia akan siap mencapai cita-cita kemerdekaan secara utuh sebagai bangsa berkarakter, cerdas, yang mampu bersaing dan bahkan berdiri sama tinggi dengan bangsa-bangsa maju lain di dunia. Dalam mewujudkan tujuan tersebut ada beberapa hal yang perlu diperhatikan dalam pendidikan vokasi, antara lain:

1. Kemajuan teknologi yang mendorong revolusi industri 4.0 bersama dengan terobosan-terbosan yang menyertainya mempengaruhi segala sector kehidupan. Untuk itu perlu diterapkan otomatisasi, artificial intelligence, big data, dll.

2. Adanya pergeseran demigrafi dan profil sosio ekonomi yang mana semakin banyak orang dengan harapan hidup lebih panjang sehingga dapat bekerja semakin lama. Dalam hal ini, sumber daya manusia sebagai tenaga kerja akan memiliki fleksibilitas dan mobilitas yang semakin tinggi yang mengaburkan Batasan antara pekerjaan dan kehidupan sehari-hari.

3. Kebutuhan akan energi akan semakin naik sedangkan ketersediaan sumber daya alam semakin menipis sehingga diperlukan adanya penggunaan energi alternatif untuk melawan dampak buruk perubahan iklim dan populasi.

4. Keterkaitan antar perubahan pada ketiga hal di atas akan membentuk dunia kerja yang berbeda. Teknologi akan mempermudah pekerjaan sehari-hari namun juga memerlukan keterampilan bagi penggunanya, dan ruang lingkup pekerjaan tidak terikat batas geografis. 
Arah kebijakan dan strategi pada pendidikan vokasi pada Kementerian Pendidikan dan Kebudayaan juga merupakan acuan dasar dari pendidikan vokasi pada Kementerian/Lembaga lain, seperti halnya pendidikan tinggi vokasi pada Kementerian Perhubungan. Undang-Undang Republik Indonesia No. 12/2012 tentang Pendidikan Tinggi menyebutkan bahwa Perguruan Tinggi merupakan bagian dari sistem pendidikan nasional yang memiliki peran strategis dalam mencerdaskan kehidupan bangsa dan memajukan ilmu pengetahuan dan teknologi dengan memperhatikan dan menerapkan nilai humaniora serta pembudayaan dan permberdayaan bangsa Indonesia yang berkelanjutan (Presiden Republik Indonesia, 2012). Secara spesifik, pendidikan vokasi bertujuan untuk menyiapkan sumber daya manusia professional dengan keterampilan kerja tinggi. Dalam hal ini, perguruan tinggi vokasi Kementerian Perhubungan perlu mengembangkan kompetensi dan profesionalitas peserta didik sehingga dapat bersaign secara global.

Untuk menciptakan pendidikan vokasi yang menghasilkan lulusan berkualitas dan kompeten, maka diperlukan tata kelola pendidikan vokasi yang sesuai standar (Hakim, 2016). Standarisasi perguruan tinggi yang telah ditetapkan oleh perguruan tinggi mencakup tujuh aspek standar yang bertujuan agar pendidikan tinggi terutama vokasi dapat diakui eksistensinya oleh stakeholders dan memiliki output yang dapat dipertanggung jawabkan kepada masyarakat pada umumnya dan masyarakat pengguna pendidikan khususnya. Adapun tujuh standar pendidikan tinggi, sebagai berikut:

1. Standard satu: visi, misi, tujuan dan sarana serta strategi pencapaian.

2. Standard dua: tata pamong, kepemimpinan, sistem pengelolana dan penjaminan mutu.

3. Standard tiga: mahasiswa dan lulusan.

4. Standard empat: sumber daya manusia.

5. Standard lima: kurikulum, pembelajaran dan suasana akademik.

6. Standard enam: pembiayaan, sarana dan prasarana serta sistem informasi.

7. Standard tujuh: penelitian, pelayanan/pengabdian masyarakat, dan kerjasama.

Dengan adanya tuntutan peningkatan kualitas pendidikan tinggi, BAN-PT telah melakukan perubahan standarisasi perguruan tinggi pada 2019 melalui perubahan instrument akreditasi perguruan tinggi 3.0 yang ditetapkan dengan Peraturan Badan Akreditasi Nasional Perguruan Tinggi Nomor 3 Tahun 2019 tentang Instrumen Akreditasi Perguruan Tinggi (BAN-PT, 2019). Standarisasi perguruan tinggi yang semula hanya terdapat tujuh kriteria, ditambahkan menjadi sembilan kriteria untuk menjamin kelayakan mutu pendidikan suatu organisasi perguruan tinggi. Adapun sembilan standar perguruan tinggi yang ditetapkan oleh BAN-PT adalah sebagai berikut:

1. Standar satu: visi, misi, tujuan dan strategi

2. Standar dua: tata pamong, tata kelola dan kerja sama.

3. Standar tiga: mahasiswa.

4. Standar empat: sumber daya manusia.

5. Standar lima: keuangan, sarana dan prasarana.

6. Standar enam: pendidikan.

7. Standar tujuh: penelitian.

8. Standar delapan: pengabdian kepada masyarakat.

9. Standar sembilan: luaran dan capaian tridharma.

Untuk mendukung standarisasi pendidikan, khususnya pada pendidikan tinggi dan secara umum pada pendidikan nasional di segala jenjang, pada tahun 2021 Pemerintah Republik Indonesia telah menetapkan standarisasi pendidikan nasional melalui Peraturan Pemerintah Republik Indonesia Nomor 57 tentang Standar Nasional Pendidikan (Indonesia, 2021). Hal tersebut dilakukan sebagai salah satu upaya mewujudkan pendidikan nasional yang terarah, terencana dan bekerlanjutan untuk meningkatkan mutu pendidikan sesuai dengan tuntutan perubaha kehidupan lokal, nasional dan global. Adapun delapan standar yang ditetapkan, yaitu: (1) Standar kompetensi lulusan; (2) Standar isi; (3) Standar proses; (4) Standar penilaian pendidikan; (5) 
4559 Analisis Tata Kelola Perguruan Tinggi Vokasi dan Indeks Kepuasan Siswa pada Politeknik Perkeretaapian Indonesia Madiun - Damar Isti Pratiwi, Septiana Widi Astuti, Armyta Puspitasari, Ainun Fikria

DOI $\quad$ : https://doi.org/10.31004/edukatif.v3i6.1491

Standar tenaga pendidikan; (6) Standar sarana dan prasarana; (7) Standar pengelolaan; dan (8) Standar pembiayaan.

Namun, arah kebijakan dan strategi yang telah disusun oleh Dirjen Pendidikan Vokasi dan dijabarkan dalam grand design SDM Perhubungan Darat oleh Pusat Pengembangan SDM Perhubungan Darat yang menjadi dasar acuan kebijakan PPI Madiun belum sepenuhnya dapat dipenuhi dan dilaksanakan. Untuk itu, perlu dilakukan evaluasi terhadap tata kelola pendidikan vokasi pada Kementerian Perhubungan khususnya pada PPI Madiun sehingga dapat memenuhi kriteria ideal sistem pendidikan vokasi sesuai yang telah ditetapkan oleh pemerintah. Analisis terhadap indeks kepuasaan siswa juga perlu dilakukan untuk mengetahui sejauh mana mahasiswa sebagai konsumen utama terpenuhi kebutuhannya melalui pendidikan vokasi yang diselenggarakan. Dengan demikian, pada penelitian ini menitik beratkan pada tiga rumusan masalah sebagai berikut:

1. Bagaimana analisis peraturan tata kelola perguruan tinggi vokasi PPI Madiun terhadap peraturan yang telah ditetapkan pemerintah melalui Direktorat Jenderal Vokasi?

2. Bagaimana analisis hasil indeks kepuasaan mahasiswa terhadap tata kelola pendidikan vokasi di PPI Madiun?

3. Bagaimana peran PPI Madiun sebagai perguruan tinggi vokasi dalam mendukung program pemerintah di sector ekonomi?

\section{METODE PENELITIAN}

Penelitian ini menggunakan metode studi kasus dengan analisis kualitatif dan kuantitatif. Pendekatan kualitatif yang digunakan merupakan hasil analisis dari beberapa sumber pustaka. Sumber utama yang digunakan adalah Rencana Strategis Direktorat Jenderal Vokasi 2020-2024, Grand Design SDM Perhubungan Darat, dan Statuta Politeknik Perkeretaapian Indonesia Madiun. Ketiga literatur tersebut juga didukung oleh sejumlah hasil penelitian mengenai pendidikan pada Perguruan Tinggi vokasi di Indonesia.

Ketiga literatur utama tersebut ditelaah dan dianalisis mengenai kesesuaian aturan-aturan yang ditetapkan oleh Direktorat Jenderal Vokasi Kementerian Pendidikan dengan grand design SDM Perhubungan Darat yang disusun oleh Pusat Pengembangan SDM Perhubungan Darat dan statuta PPI Madiun yang telah ditetapkan oleh Menteri Perhubungan Republik Indonesia. Hasil telaah ketiga literatur utama yang didukung dengan sejumlah jurnal hasil penelitian, kemudian dianalisis untuk menghasilkan sebuah konsep yang holistik dan komprehensif tentang PPI Madiun sebagai organisasi perguruan tinggi vokasi, dan peran PPI Madiun dalam pengembangan ekonomi Indonesia (Pertiwi \& Pusparini, 2021).

Pendekatan kuantitatif yang digunakan merupakan hasil analisis indeks kepuasaan siswa terhadap tata kelola perguruan tinggi vokasi. Pada metode ini digunakan analisis korelasi dengan menerapkan korelasi koefisien Pearson pada SPSS 20. Hal ini digunakan untuk mengetahui hubungan antara tata kola perguruan tinggi vokasi pada PPI Madiun dengan indeks kepuasaan siswa yang menjadi konsumen utama lembaga sebagai penyedia layanan pendidikan. Data indeks kepuasaan siswa didapatkan dari Unit Satuan Penjamin Mutu PPI Madiun yang telah menyebarkan kuesioner setiap semester terhadap siswa.

\section{HASIL DAN PEMBAHASAN}

\section{PPI Madiun Sebagai Organisasi Perguruan Tinggi Vokasi}

Dunia pendidikan idealnya berdasarkan pada pemberian layanan yang sesuai dengan standar pendidikan, yang mana untuk pendidikan tinggi terdapat tujuh standard yang telah ditetapkan oleh Badan Akreditasi Nasional Perguruan Tinggi (BAN-PT). Perubahan-perubahan yang telah dan sedang dilakukan oleh berbagai perguruan tinggi khususnya perguruan tinggi vokasi di Indonesia berbentuk perubahan tata kelola 
4560 Analisis Tata Kelola Perguruan Tinggi Vokasi dan Indeks Kepuasan Siswa pada Politeknik Perkeretaapian Indonesia Madiun - Damar Isti Pratiwi, Septiana Widi Astuti, Armyta Puspitasari, Ainun Fikria

DOI $\quad$ : https://doi.org/10.31004/edukatif.v3i6.1491

dan manajemen pelayanan yang diberikan kepada masyarakat dan stakeholders untuk meningkatkan kualitas pendidikan (Ubaedillah \& Pratiwi, 2021). Dalam hal ini, negara hadir pula dalam wujud pemberian regulasi yang melindungi dan mengayomi kepentingan publik yang diwujudkan dalam tata kelola organisasi pendidikan. Berbagai macam undang-undang dan aturan-aturan terkait yang berkaitan dengan pelayanan pendidikan telah diterbitkan.

Politeknik Perkeretaapian Indonesia (PPI) Madiun merupakan perguruan tinggi vokasi yang berada di bawah naungan Kementerian Perhubungan dan bertanggung jawab kepada Kepala Badan Pengembangan Sumber Daya Manusia (BPSDM) Perhubungan sesuai dengan statuta PPI Madiun pada Peraturan Menteri Perhubungan Republik Indonesia Nomor PM 43 Tahun 2019 (Perhubungan, 2019). Pada Grand Design SDM Transportasi Darat Pusat Pengembangan SDM Perhubungan Darat disebutkan bahwa tradisi pendidikan vokasi pada perguruan tinggi yang bertanggung jawab kepada BPSDM Perhubungan bertujuan untuk menyiapkan lulusan yang siap kerja sehingga pendidikan vokasional seharusnya memuat pelatihan khusus yang bersifat reproduktif dengan fokus perhatian pada pengembangan kebutuhan industri dan ketrampilanketrampilan khusus yang dibutuhkan (Perhubungan, 2020). Dalam hal ini, PPI Madiun mempunyai tugas menyelenggarakan program pendidikan vokasi, penelitian, dan pengabdian kepada masyarakat di bidang perkeretaapian.

Karakteristik pendidikan vokasi yang merupakan penggabungan antara pendidikan dan pelatihan memiliki peluang untuk mengembangkan manusia seutuhnya dengan cara mengembangkan kompetensi sesuai dengan Standard Nasional Perguruan Tinggi yang meliputi Standard Pengajararan, Standard Penelitian, dan Standard Pengabdian Masyarakat (Perhubungan, 2020). Standar Nasional Pendidikan adalah kriteria minimal tentang sistem pendidikan di seluruh wilayah hukum Negara Kesatuan Republik Indonesia. Standar Penelitian adalah kriteria minimal tentang sistem Penelitian pada perguruan tinggi yang berlaku di seluruh wilayah hukum Negara Kesatuan Republik Indonesia. Standar Pengabdian kepada Masyarakat adalah kriteria minimal tentang sistem Pengabdian - kepada Masyarakat pada perguruan tinggi yang berlaku di seluruh wilayah hukum Negara Kesatuan Republik Indonesia.

PPI Madiun sebagai perguruan tinggi vokasi memiliki visi sebagai pusat unggulan dan inovasi pendidikan dan pelatihan vokasi di bidang teknis perkeretaapian berbasi teknologi global pada tahun 2030 yang tertuang dalam statuta PPI Madiun pasal ke 38 (Perhubungan, 2020). Untuk itulah dalam mewujudkan visi yang ada, PPI Madiun telah menentukan serangkaian misi sebagai perwujudan langkah dalam mewujudkan cita-cita yang ada, yaitu:

1. Mewujudkan lembaga pendidikan dan pelatihan tinggi yang unggul, transparan dan akuntabel.

2. Menyelenggarakan dan mengembangkan pendidikan dan pelatihan vokasi yang berbasis kompetensi dan perkembangan teknologi perekeretaapian serta mengintegrasikan pembelajaran kepribadian yang prima, professional dan beretika.

3. Mengembangkan ilmu pengetahuan dan teknologi melalui penelitian terapan di bidang teknis perkeretaapian serta berdaya saing secara global.

4. Melaksanakan pengabdian masyarakat melalui penerapan teknologi tepat guna untuk mengingkatkan keselamatan penyelenggaraan transportasi perkeretaapian.

5. Menjalin kerjasama dengan berbagai institusi baik di dalam maupun di luar sub sektor perkeretaapian dalam rangka pembangunan Sumber Daya Manusia.

Visi dan misi yang ditetapkan oleh PPI Madiun bertujuan untuk menghasilkan lulusan yang mempunyai pengetahuan, pemahaman, dan kecakapan di bidang perkeretaapian serta memiliki integritas dan profesionalisme yang tinggi serta berbudi pekerti luhur. Hal tersebut sesuai dengan arah kebijakan Pusat Pengembangan SDM Perhubungan Darat mengenai link and match pendidikan vokasi yang menyatakan bahwa pendidikan vokasional cocok untuk dijadikan sebagai model dan lokomotif pengembangan SDM bangsa Indonesia yang menghasilkan output yang memiliki kemampuan kompetitif dan penguasaan 
4561 Analisis Tata Kelola Perguruan Tinggi Vokasi dan Indeks Kepuasan Siswa pada Politeknik Perkeretaapian Indonesia Madiun - Damar Isti Pratiwi, Septiana Widi Astuti, Armyta Puspitasari, Ainun Fikria

DOI $\quad$ : https://doi.org/10.31004/edukatif.v3i6.1491

kompetensi yang memadai. Namun tentunya hal ini juga harus diimbangi oleh pengembangan yang secara terus-menerus, berkelanjutan dan sistematis pada tingkat nasional dan institusional sehingga dapat tercipta sistem pendidikan vokasi yang sesuai.

Perubahan yang dilakukan oleh PPI Madiun sebagai perguruan tinggi vokasi dilakukan dalam rangka menjawab tantangan global untuk menunjukkan eksistensi perguruan tinggi yang dinamis dan positif untuk perkembangan organisasi yang lebih baik (Sari et al., 2013).Terdapat tiga proses yang perlu dilalui dalam menjawab tantangan perubahan yaitu: (1) Unfreezing: suatu proses penyadaran tentang perlunya kebutuhan untuk berubah; (2) Changing: langkah yang berupa tindakan baik untuk memperkuat driving force dan memperlemah resistence; (3) Refreezing: membawa kembali organisasi kepada keseimbangan yang baru ( $a$ new equilibrium).

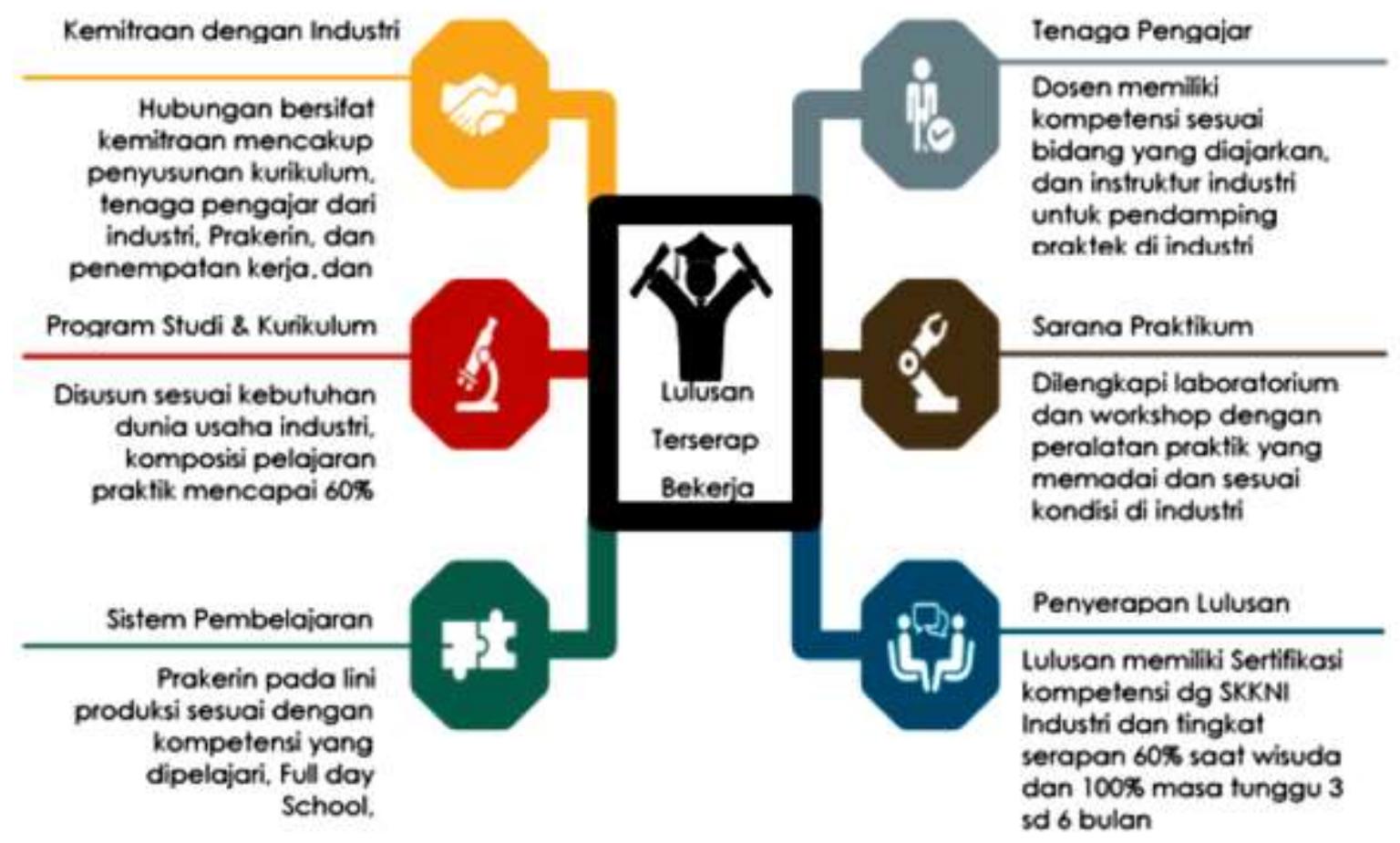

Gambar 1. Link and Match Pendidikan Vokasi

Pusat Pengembangan SDM Perhubungan Darat

Langkah awal dalam menyusun perubahan untuk meningkatkan kualitas pendidikan adalah melalui peningkatan mutu pendidikan. Ketiga proses perubahan tersebut di atas selanjutnya dapat dijabarkan dalam delapan langkah nyata dalam perubahan peningkatan kualitas pendidikan sebagai berikut (Putera \& Shofiah, 2021):

1. Diagnosing needs.

PPI Madiun melalui para pengajar (dosen) mengidentifikasi masalah, kebutuhan dan kondisi peserta didik (taruna) dalam suatu proses pembelajaran. Proses identifikasi masalah didasarkan pada latar belakang dan tujuan dari organisasi PPI Madiun yang telah ditetapkan.

2. Formulating specific objectives.

Formulasi tujuan-tujuan khusus yang merupakan penjabaran dari tujuan umum PPI Madiun perlu disusun secara menyeluruh berdasarkan kebutuhan-kebutuhan yang telah diidentifikasi terutama pada sistem pengajaran. 
4562 Analisis Tata Kelola Perguruan Tinggi Vokasi dan Indeks Kepuasan Siswa pada Politeknik Perkeretaapian Indonesia Madiun - Damar Isti Pratiwi, Septiana Widi Astuti, Armyta Puspitasari, Ainun Fikria

DOI $\quad$ : https://doi.org/10.31004/edukatif.v3i6.1491

3. Selecting content.

Pemilihan materi pengajaran pada PPI Madiun didasarkan pada kesepadanan dengan tujuan khusus dengan mempertimbangkan tingkat validitas, realibitas dan signifikansi materi. Pada tahap ini diperlukan seleksi terhadap tingkatan materi yang diberikan kepada peserta didik yang meliputi pemilihan topik utama, pemilihan ide-ide dasar dan pemilihan materi khusus.

4. Organizing content.

Pengorganisasian materi pada sistem pengajaran di PPI Madiun dilakukan berdasarkan tingkat kemampuan awal dan minat para peserta didik dengan memperhatikan tingkat kesulitan materi sehingga perlu disusun dari materi abstract ke konkrit.

5. Selecting learning experience (Activities).

Pengalaman belajar di PPI Madiun disusun dengan tujuan terjadi interaksi antara pengajar dan peserta didik melalui materi pembelajaran yang disusun. Setiap materi yang dipilih mempunyai tujuan dan fungsi tertentu yang mendung tujuan utama PPI Madiun sebagai sebuah organisasi perguruan tinggi vokasi. Untuk itu, dalam pemilihan pengalaman belajar perlu diperhatikan kesesuaian kegiatan dengan ide-ide utama pembelajaran dan tujuan umum dan khusus organisasi, dalam hal ini PPI Madiun. Selain itu, perlu diperhatikan juga mengenai efisiensi kegiatan yang meningkatkan kegiatan belajar dan mengembangkan ketrampilan peserta didik.

6. Organizing learning experience activities.

Pengalaman belajar para peserta didik di PPI Madiun diorganisasikan dengan sekuensi dan organisasi materi yang secara holistic diarahkan dari induktif ke generalisasi dan abtraksi. Hal ini tersebut bertujuan untuk memfokuskan pengembangan ide-ide utama dan langkah-langkah perolehan konsep sehingga menghasilkan output yang kompeten dan memiliki ketrampilan yang memadai untuk memasuki dunia kerja.

7. Evaluating.

Evaluasi pada proses pendidikan di PPI Madiun bertujuan untuk mengetahui tingkat pencapaian pada materi pembelajaran pada khususnya dan tujuan PPI Madiun sebagai pendidikan tinggi vokasi secara umum. Selanjutnya hasil evaluasi dapat dipergunakan sebagai langkah untuk menentukan tujuan umum dan khusus organisasi, diagnosis masalah organisasi dan peserta didik, dan penilaian dalam rangka pengembangan dan revisi standard pendidikan.

8. Checking for balance and Sequence.

Pengecekan konsistensi antar semua bagian organisasi dengan tujuan organisasi pada proses pendidikan di PPI Madiun perlu dilakukan secara kontinu sehingga proses pembelajaran pada PPI Madiun mendukung pengembangan kompetensi peserta didik.

Direktorat Jenderal Pendidikan Vokasi menetapkan delapan kompetensi lulusan yang mencakup soft skills dan hardskills pada Rencana Strategis Ditjen Pendidikan Vokasi 2020-2024 yang merupakan pengembangan dari tujuh kompetensi vokasi oleh Wagner (Ditjen Pendidikan Vokasi, 2020), yaitu: (1) Communication skills; (2) Critical and creative thinking; (3) Information/digital literacy; (4) Iinquiry/reasoning skills; (5) Interpersonal skills; (6) Multicultural/multilingual literacy; (7) Problem solving;(8) Technological skills. Dalam mencapai kompetensi lulusan pendidikan tinggi vokasi, terdapat tiga model kampus vokasi, yaitu (Widarman, 2017):

1. Perguruan Tinggi vokasi produksi sederhana (simple production).

Model pertama ini mempunyai ciri khas yang mana kegiatan produksi dan pendidikan tercakup dalam lembaga dan bentuk organisasinya ditentukan oleh peraturan yang birokratis. Kampus telah dilengkapi dengan bengkel sebagai tempat praktek. Namun pergerakan ke luar kampus terbatas dan simulasi realitas perusahaan masih setaraf dengan perusahaan pekerjaan tangan. 
4563 Analisis Tata Kelola Perguruan Tinggi Vokasi dan Indeks Kepuasan Siswa pada Politeknik Perkeretaapian Indonesia Madiun - Damar Isti Pratiwi, Septiana Widi Astuti, Armyta Puspitasari, Ainun Fikria

DOI $\quad$ : https://doi.org/10.31004/edukatif.v3i6.1491

2. Perguruan Tinggi vokasi produksi berkembang (training and production).

Model kedua ini merupakan penggabungan antara kegiatan pendidikan dengan kegiatan produksi yang mana bengkel untuk produksi dan pendidikan terpisah. Sistem perguruan tinggi tidak terikat dengan peraturan sekolah yang birokratis sehingga cenderung lebih bebas dan taraf simulasi perusahaan telah setaraf dengan perusahaan manufaktur.

3. Perguruan Tinggi vokasi produksi berkembang bentuk pabrik dan tempat belajar (production training corporation).

Model ketiga ini disebut juga teaching factory model. Penyelenggaraan pendidikan memadukan sepenuhnya antara belajar dan bekerja. Bentuk organisasi pada perguruan tinggi menunjukkan karakteristik perusahaan dan taraf simulasi perusahaan setingkat dengan pembuatan barang jadi yang modern.

Menurut pendapat Sudira (2012), sekolah vokasi mempunyai empat model, yaitu: (1) model sekolah; (2) model sistem ganda; (3) model magang; dan (4) model school-based enterprise. Model pendidikan vokasi yang diungkapkan oleh Sudira lebih mengacu pada tingkat Sekolah Menengah Kejuruan (SMK), tetapi dapat dijadikan sebagai referensi sekolah vokasi pada pendidikan tinggi dimana setiap model sekolah vokasi mempunyai karakteristik dan ciri-ciri khusus yang melekat namun tetap pada tatanan yang sama yakni mengembangkan kompetensi keahlian untuk siap memasuki dunia kerja. Pada model yang pertama, yaitu model sekolah, pendidikan dan pelatihan dilakukan sepenuhnya di sekolah, sehingga pihak sekolah perlu menyediakan dan melengkapi peralatan dalam jumlah yang besar. Dalam hal ini, biaya sekolah akan menjadi sangat mahal dan kegiatan pembelajaran menjadi kurang efektif dan efisien akibat tingkat keusangan alat yang cukup tinggi dan perkembangan teknologi yang sangat cepat. Pada model kedua, model sistem ganda, penyelenggaraan pendidikan dan latihan merupakan perpaduan pemberian pengalaman belajar di sekolah dan pengalaman kerja sarat nilai di dunia usaha. Model ini sangat baik karena menganggap pembelajaran di sekolah dan pengalaman kerja di dunia usaha akan saling melengkapi, lebih bermakna, dan nyata.

Model yang ketiga adalah model magang, dimana kegiatan pelatihan diserahkan sepenuhnya kepada industri dan masyarakat tanpa dukungan sekolah. Pihak sekolah hanya menyelenggarakan pendidikan mata pelajaran normatif, adaptif, dan dasar-dasar kejuruan. Namun, model pendidikan ini belum sepenuhnya bisa diterapkan di Indonesia dikarenakan belum siapnya industri dan masyarakat untuk mendukung hal tersebut. Model magang ini lebih cocok diterapkan di negara-negara maju yang telah memiliki sistem pendidikan dan industri yang kuat. Model yang terakhir yakni school-based enterprise memiliki sistem dengan mengembangkan dunia usaha di sekolah. Hal ini bertujuan untuk menambah penghasilan sekolah dan sepenuhnya memberikan pengalaman kerja yang benar-benar nyata dan sarat nilai kepada peserta didik. Beberapa sekolah, terutama SMK di Indonesia telah menerapkan sistem ini. Sebagai contoh SMKN 1 Sewon Bantul yang mengembangkan Education Hotel di daerah Kasongan dengan melibatkan peserta didik mulai dari house keeping hingga front office.

Sesuai dengan visi PPI Madiun, sekarang ini model pembelajaran pendidikan vokasi berada dalam model pertama. Namun melalui analisis kebutuhan dan langkah-langkah perubahan pendidikan vokasi, PPI Madiun diharapkan dapat bergerak pada model kedua bahkan ketiga dari model pendidikan vokasi sehingga para peserta didik dapat langsung berperan aktif dalam proses produksi barang layak jual. Secara ekonomis, model kedua dan ketiga juga dapat mendukung pembiayaan organisasi sehingga dapat meningkatkan mutu dan layanan kualitas pendidikan yang dijalankan. Unit produksi merupakan salah satu embrio strategis bagi berkembangnya teaching factory yang berguna bagi peningkatan kompetensi para peserta didik dan pengelolaan tata kelola organisasi perguruan tinggi vokasi yang lebih efektif dan efisien. 
4564 Analisis Tata Kelola Perguruan Tinggi Vokasi dan Indeks Kepuasan Siswa pada Politeknik Perkeretaapian Indonesia Madiun - Damar Isti Pratiwi, Septiana Widi Astuti, Armyta Puspitasari, Ainun Fikria

DOI : https://doi.org/10.31004/edukatif.v3i6.1491

\section{Hasil Analisis Indeks Kepuasaan Siswa terhadap Tata Kelola PPI Madiun}

Perubahan global yang terjadi di seluruh dunia akibat kemajuan teknologi merupakan hal yang tidak dapat dihindari (Pratiwi \& Ubaedillah, 2021). Negara selaku regulator pendidikan telah menetapkan serangkaian langkah untuk menjawab tantangan perubahan tersebut, yakni salah satunya membentuk Direktorat Jenderal Pendidikan Vokasi di bawah Kementerian Pendidikan dan Kebudayaan. Direktorat Jenderal Pendidikan Vokasi menyusun rencana strategis pendidikan vokasi untuk meningkatkan kualitas pendidikan sehingga dapat menghasilkan lulusan yang berkompeten dan siap terjun pada dunia kerja. Hal tersebut tentunya juga menjadi acuan bagi Perguruan Tinggi Vokasi pada Kementerian/Lembaga lain, tidak terkecuali Kementerian Perhubungan. Pada rencana strategis Direktorat Jenderal Vokasi telah ditetapkan mengenai Indeks Kepuasaan Siswa yang diukur setiap akhir semester sebagai bahan evaluasi untuk peningkatan layanan pendidikan.

Indeks Kepuasaan Siswa pada PPI Madiun didapatkan melalui kuesioner yang diberikan setiap semester kepada Mahasiswa melalui Unit Satuan Penjamin Mutu. Pada penelitianini, hasil dari kuesioner dihitung menggunakan koefisien korelasi Pearson ( $r$ coefficient) yang digunakan untuk menghitung hubungan antara indeks kepuasaan siswa terhadap tata kelola PPI Madiun. Tabel 1 di bawah ini menunjukkan hasil analisis koefisien Pearson.

Tabel 1. Korelasi Indeks Kepuasaan Siswa terhadap Tata Kelola PPI Madiun

\begin{tabular}{lllrrr}
\hline & & $\begin{array}{l}\text { Indeks } \\
\text { Siswa }\end{array}$ & Kepuasaan & $\begin{array}{l}\text { Tata } \\
\text { Madiun }\end{array}$ & Kelola \\
\hline Indeks & Kepuasaan & Korelasi & & 1 & \\
Siswa & Pearson & & & & \\
\hline & Sig (2-tailed) & & & 600 \\
\hline & $\mathrm{N}$ & 67 & 1 \\
\hline Tata Kelola PPI Madiun & Korelasi & & \\
& Pearson & & & \\
\hline & Sig (2-tailed) & 67 & 67 \\
\hline
\end{tabular}

Data pada tabel 1 menunjukkan $\mathrm{r}=0.598 ; \mathrm{p}(2$ tailed $)=0$; dan $\mathrm{N}=617$. Hal ini menunjukkan bahwa tata kelola perguruan tinggi vokasi, khususnya pada PPI Madiun yang sesuai dengan Rencana Strategis Direktorat Jendela Vokasi dan grand design SDM Perhubungan Darat, menghasilkan indeks kepuasaan siswa yang tinggi. Sehingga hasil korelasi menunjukkan hubungan yang kuat dan signifikan dengan adanya perkembangan yang dinamis dan efektif terhadap tata kelola PPI Madiun.

Peningkatan layanan pendidikan melalui perubahan tata kelola PPI Madiun telah sesuai dengan grand design pengembangan sumber daya manusia perhubungan darat yang dibuat oleh Pusat Pengembangan Sumber Daya Manusia Perhubungan Darat yang menaungi PPI Madiun. Grand design ini digunakan acuan untuk meningkatkan kualitas SDM Perhubungan Darat dan sebagai dasar PPI Madiun untuk betransformasi pada tata kelola perguruan tinggi vokasi dengan mengikuti pola manajemen strategi yang terukur. Perubahan mendasar yang telah dilakukan yakni adanya perubahan dari Akademi menjadi Politeknik yang diikuti dengan serangkaian perubahan visi, misi, tujuan dan tata kelola organisasi. Dengan dilakukan perubahan tersebut diharapkan dapat menghasilkan lulusan yang profesional di bidang perkeretaapian di Indonesia.

Perbaikan terhadap layanan pendidikan pada umumnya diikuti dengan indeks kepuasaan siswa yang tinggi (Putera \& Shofiah, 2021; Slamet, 2011). Hal tersebut tentunya dapat mendorong perguruan tinggi vokasi untuk dapat meningkatkan kualitas layanan pendidikan melalui perbaikan tata kelola yang akan diikuti oleh indeks kepuasaan stakeholders terhadap lulusan sehingga dapat meningkatkan daya serap lulusan yang 
4565 Analisis Tata Kelola Perguruan Tinggi Vokasi dan Indeks Kepuasan Siswa pada Politeknik Perkeretaapian Indonesia Madiun - Damar Isti Pratiwi, Septiana Widi Astuti, Armyta Puspitasari, Ainun Fikria

DOI $\quad$ : https://doi.org/10.31004/edukatif.v3i6.1491

berpotensi mendukung program pemerintah dalam perbaikan perekonomian Negara khususnya di masa pandemi sekarang ini dimana kondisi perekonomian sedang lumpuh.

Namun, hasil indeks kepuasaan siswa yang tinggi harus terus dipertahankan dan dijadikan sebagai acuan untuk terus maju dan berkembang. Evaluasi terkait tata kelola perguruan tinggi vokasi harus terus menerus dilakukan yang kemudian diikuti oleh perubahan-perubahan dinamis dan fleksibel oleh PPI Madiun. Dikarenakan ilmu pengetahuan dan teknologi yang juga terus berkembang, sehingga perubahan merupakan sesuatu yang tidak dapat dihindari untuk tetap dapat memiliki eksistensi sebagai penghasil lulusan yang berkualitas (Pratiwi et al., 2021). Hasil akhir dari perkembangan tata kelola perguruan tinggi vokasi di PPI Madiun diharapkan dapat menghasilkan output yang berguna bagi masyarakat, stakeholders dan mendukung pertumbuhan ekonomi Indonesia secara umum.

\section{Peran PPI Madiun Dalam Pembangunan Ekonomi Indonesia}

Esensi proses pendidikan pada dasarnya adalah dari masyarakat untuk masyarakat, oleh karena itu, perbaikan kualitas pendidikan selalu mengacu pada kebutuhan dan pemecahan masalah yang dihadapi oleh masyarakat. Seperti halnya PPI Madiun yang telah bertransformasi dari sebelumnya Akademi Perkeretaapian Indonesia (API) Madiun dengan diikuti serangkain perubahan visi, misi dan tujuan agar sesuai dengan kebutuhan masyarakat dan perkembangan dunia yang telah berbasis pada revolusi industri 4.0. Perubahan ini juga berdasarkan bahwa pendidikan merupakan pranata utama penyiapan SDM yang menentukan kualitas SDM yang hasil akhirnya juga mempengaruhi pertembuhan ekonomi bangsa Indonesia. Argumentasi mengenai pentingnya penyiapan SDM ini selaras dengan yang tertuang pada grand design SDM Transportasi Darat (Perhubungan, 2020).

Dari sisi ekonomi, pendidikan bukan hanya merupakan kegiatan konsumtif tetapi juga merupakan sebuah investasi untuk memberikan sumbangan terhadap pembangunan sosial ekonomi melalui cara-cara peningkatan pengetahuan, ketrampilan, kecakapan, sikap dan produktivitas. Pada semua pendidikan vokasi, utamanya pada pendidikan tinggi vokasi, lulusan dipersiapkan siap memasuki dunia kerja yang memiliki peran strategis (Hartanto \& Haryani, 2020). Di PPI Madiun, kompetensi lulusan ditekankan secara spesifik pada kompetensi bidang perkeretapian yang terus berkembang pesat di Indonesia sebagai salah satu moda transportasi masal yang aman, nyaman dan terjangkau. Hal tersebut sesuai dengan tujuan pengembangan SDM Transportasi Darat sebagai induk PPI Madiun, bahwa diperlukan link and match pendidikan vokasi perguruan tinggi vokasi di level nasional dan institusional.

Dengan dicanangkannya Masyarakat Ekonomi ASEAN (MEA) pada tahun 2015, peningkatan kompetensi SDM harus lebih dipacu secara efektif dan efisien yang disesuaikan dengan kebutuhan pasar dimana persaingan pasar bebas di kawasan ASEAN akan semakin terbuka (Ubaedillah et al., 2021). Perguruan tinggi vokasi di Indonesia perlu menyiapkan manajemen strategi untuk mencapai tujuan perubahan dengan keberhasilan maksimal. Menurut Pearce dan Robinson (2007), manajemen strategi terdiri dari 9 aspek penting sebagai berikut:

1. Merumuskan misi perusahaan, termasuk pernyataan umum tentang tujuan, filosofi, dan sasaran.

2. Melakukan analisis yang mencerminkan kondisi dan kapabilitas internal perusahaan.

3. Menilai lingkungan eksternal perusahaan, baik kompetisi dan faktor-faktor kontekstual umumnya.

4. Menganalisis opsi-opsi perusahaan dengan menyesuaikan sumber daya yang dimilikinya dengan lingkungan eksternalnya.

5. Mengenali opsi-opsi yang paling diinginkan dengan mengevaluasi setiap opsi berdasarkan misi perusahaan.

6. Memilih seperangkat sasaran jangka panjang dan strategi besar yang mampu mencapai hasil yang paling diinginkan. 
4566 Analisis Tata Kelola Perguruan Tinggi Vokasi dan Indeks Kepuasan Siswa pada Politeknik Perkeretaapian Indonesia Madiun - Damar Isti Pratiwi, Septiana Widi Astuti, Armyta Puspitasari, Ainun Fikria

DOI $\quad$ : https://doi.org/10.31004/edukatif.v3i6.1491

7. Mengembangkan sasaran tahunan dan strategi jangka pendek yang sesuai dengan pilihan seperangkat sasaran jangka panjang dan strategi besar.

8. Menerapkan pilihan-pilihan strategik melalui pengalokasian sumber daya yang dianggarkan, dimana kesesuain tugas-tugas, karyawan, struktur, teknologi, dan sistem imbalan ditekankan.

9. Mengevaluasi keberhasilan proses strategik sebagai masukan bagi pengambiklan keputusan di masa depan.

Transformasi yang telah dilakukan PPI Madiun telah melalui sembilan aspek penting dari manajemen strategi. Hal ini diharapkan mampu menjawab akselerasi kualitas mutu sehingga dapat lulusan PPI Madiun dapat bersaing di dunia kerja tingkat lokal maupun mengglobal dengan bersaing di tingkat ASEAN melalui penerapan MEA yang saat ini telah berjalan. Namun, evaluasi dan perubahan secara konsisten dan terus menerus melalui konsep manajemen strategi terus dilakukan di PPI Madiun dalam rangka mencapai kualitas mutu yang lebih baik untuk mendukung daya saing SDM Indonesia di dunia. PPI Madiun menjawab tantangan kemajuan ilmu pengetahuan dan teknologi dengan meningkatkan kualitas pelayanan pendidikan prima dengan melakukan perubahan-perubahan aspek strategis yang diperlukan. Perumusan ulang visi, misi dan tujuan organisasi PPI Madiun sebagai perguruan tinggi vokasi telah dilakukan dalam rangka menghasilkan kualitas lulusan yang berkualitas dan dapat diterima pada dunia global untuk mendukung pertumbuhan ekonomi Indonesia.

\section{KESIMPULAN}

Hasil analisis terkait peraturan dan kebijakan PPI Madiun sebagai perguruan tinggi vokasi telah sesuai dengan rencana strategis pendidikan vokasi pada Direktorat Jenderal Vokasi Kementerian Perhubungan dan grand design SDM Perhubungan Darat. Evaluasi kebijakan harus terus menerus dilakukan secara menyeluruh untuk menyesuiakan perkembangan global pada revolusi industri 4.0 dan learning 5.0 melalui serangkaian manajemen strategi yang efektif dan efisien. Analisis indeks kepuasaan siswa menunjukkan hasil yang signifikan terhadap peningkatan layanan pendidikan pada PPI Madiun. Hasil akhir dari tata kelola pendidikan vokasi yang sesuai dengan perkembangan dunia diharapkan dapat menghasilkan lulusan yang berkualitas untuk mendukung pertumbuhan ekonomi Indonesia. Dengan demikian, tujuan penelitian terhadap analisis tata kelola pendidikan vokasi dan indeks kepuasaan siswa pada PPI Madiun telah terpenuhi.

\section{DAFTAR PUSTAKA}

Amin, S. (2017). Strategi Peningkatan Kualitas Pelayanan Akademik Pada Perguruan Tinggi. Jurnal Madaniyah, 7(2).

BAN-PT, B. A. N. P. T. (2019). Peraturan Badan Akreditasi Nasional Perguruan Tinggi Nomor 3 Tahun 2019 Tentang Instrumen Akreditasi Perguruan Tinggi. Badan Akreditasi Nasional Perguruan Tinggi (BAN-PT).

Ditjen Pendidikan Vokasi. (2020). Rencana Strategis Direktorat Jenderal Pendidikan Vokasi Tahun 20202024. Ditjen Pendidikan Vokasi.

Hakim, L. (2016). Manajemen Perguruan Tinggi Menuju Perubahan Kualitas Layanan Mutu. Jurnal Al Ta'dib, 6(1), 32-43.

Hartanto, C. F. B., \& Haryani, H. (2020). Analisis Tata Kelola Standar Pendidik Dan Tenaga Kependidikan Pada Pendidikan Tinggi Vokasi Kemaritiman Di Indonesia. Jurnal Sains Teknologi Transportasi Maritim, 2(1), 20-29. Https://Doi.Org/10.51578/J.Sitektransmar.V2i1.14

Indonesia, P. R. (2021). Peraturan Pemerintah Republik Indonesia Nomor 57 Tentang Standar Nasional Pendidikan. Kementerian Sekretariat Negara. 
4567 Analisis Tata Kelola Perguruan Tinggi Vokasi dan Indeks Kepuasan Siswa pada Politeknik Perkeretaapian Indonesia Madiun - Damar Isti Pratiwi, Septiana Widi Astuti, Armyta Puspitasari, Ainun Fikria

DOI : https://doi.org/10.31004/edukatif.v3i6.1491

Indrawan, I., Wijoyo, H., Sutarna, A., \& Usada, B. (2020). Manajemen Pendidikan Vokasi (1st Ed.). CV. Pena Persada.

Menteri Perhubungan. (2019). Peraturan Menteri Perhubungan Republik Indonesia Nomor PM 43 Tahun 2019 Tentang Organisasi Dan Tata Kerja Politeknik Perkeretaapian Indonesia Madiun. Kementerian Perhubungan Republik Indonesia.

Menteri Perhubungan. (2020). Peraturan Menteri Perhubungan Republik Indonesia Nomot PM 81 Tahun 2020 Tentang Statuta Politeknik Perkeretaapian Indonesia Madiun. Kementerian Perhubungan Republik Indonesia.

Pearce, J. A., \& Robinson, R. B. (2007). Startegic Management: Formulation, Implementation And Control (1st Ed.). Mcgraw-Hill Education.

Pertiwi, A. K., \& Pusparini, R. (2021). Vocational High School English Teachers' Perspectives On "Merdeka Belajar" Curriculum. Edukatif: Jurnal Ilmu Pendidikan, 3(5), 1982-1992. Https://Edukatif.Org/Index.Php/Edukatif/Article/View/672

Pratiwi, D. I., Atmaja, D. S., \& Prasetya, H. W. (2021). Multiple E-Learning Technologies On Practicing TOEFL Structure And Written Expression. JEES (Journal Of English Educators Society), 6(1), 105115. Https://Doi.Org/10.21070/Jees.V6i1.1194

Pratiwi, D. I., \& Ubaedillah, U. (2021). Digital Vocabulary Class In English For Railway Mechanical Technology. Teaching English With Technology, 21(3), 67-88.

Presiden Republik Indonesia. (2012). Undang-Undang Republik Indonesia Nomor 12 Tahun 2012 Tentang Pendidikan Tinggi. Kementerian Sekretariat Negara.

Presiden Republik Indonesia. (2019). Peraturan Presiden RI No. 82 Tahun 2019 Tentang Kementrian Pendidikan Dan Kebudayaan. Kementerian Sekretariat Negara.

Pusat Pengembangan SDM Perhubungan Darat. (2020). Penyusunan Grand Design SDM Transportasi Darat.

Putera, Z. F., \& Shofiah, N. (2021). Model Kurikulum Kompetensi Berpikir Pada Pembelajaran Bahasa Indonesia Di Perguruan Tinggi Vokasi. Metalingua - Jurnal Pendidikan Bahasa Dan Sastra Indonesia, 6(1), 29-36.

Sari, D. S. N., Singgih, M. L., \& Karningsih, P. D. (2013). Integrasi Metode Servqual, QFD, Dan Topsis Untuk Peningkatan Kualitas Pelayanan. Simposium Nasional Teknologi Terapan (SNTT), 1.

Slamet, P. (2011). Peran Pendidikan Vokasi Dalam Pembangunan Ekonomi. Cakrawala Pendidikan, Juni(2), 189-203.

Sudira, P. (2012). Filosofi Dan Teori Pendidikan Vokasi Dan Kejuruan (1st Ed., Vol. 53, Issue 9). UNY Press.

Ubaedillah, U., \& Pratiwi, D. I. (2021). Utilization Of Information Technology During The Covid- 19 Pandemic : Student's Perception Of Online Lectures. Edukatif: Jurnal Ilmu Pendidikan, 3(2), 447-455.

Ubaedillah, U., Pratiwi, D. I., Huda, S. T., \& Kurniawan, D. A. (2021). An Exploratory Study Of English Teachers: The Use Of Social Media For Teaching English On Distance Learning. IJELTAL (Indonesian Journal Of English Language Teaching And Applied Linguistics), 5(2), 361-372.

Wagner, T. (2008). The Global Achievement Gap: Why Even Our Best Schools Don't Teach The New Survival Skills Our Children Need-And What We Can Do About It (1st Ed.). Basic Books.

Widarman, A. (2017). Usulan Rancangan Peningkatan Kualitas Pelayanan Dalam Penyelenggaraan Pendidikan Dengan Pendekatan Model Integrasi Servqual, Kano Dan QFD.

Model Pendidikan Vokasi Yang Efektif Dan Efisien, (2008). 